\title{
An Overview of the Musculoskeletal Comorbidity of Acromegaly: A Case with Non-traumatic Spontaneous Rectus Femoris Rupture
}

\author{
Akromegalinin Kas-iskelet Sistemi Komorbiditesine Genel Bir Bakış: Travmatik Olmayan \\ Spontan Rektus Femoris Rüptürü Olgusu
}

Tokat Gaziosmanpaşa University Faculty of Medicine, Department of Physical Medicine and Rehabilitation, Tokat, Turkey

\section{Abstract}

Acromegaly is a chronic endocrinopathy with pathologically increased levels of growth hormone (GH) and insulin-like growth factor-1 due to a pituitary adenoma that produces $\mathrm{GH}$. One of the partially irreversible complications of acromegaly is arthropathy associated with severe morbidity in these patients. Joint complaints, such as pain, stiffness, or functional limitations, often occur with typical radiological abnormalities at an early age. We present a case of a 24-year-old acromegalic male patient with non-traumatic spontaneous right rectus femoris muscle rupture and an accompanying intramuscular haematoma.

Keywords: Acromegaly, growth hormone, muscle rupture

\section{Öz}

Akromegali, büyüme hormonu $(\mathrm{BH})$ üreten hipofiz adenomuna bağlı olarak patolojik olarak artmış BH ve insülin benzeri büyüme faktörü-1 seviyelerinin söz konusu olduğu kronik bir endokrinopatidir. Akromegalinin kısmen geri dönüşümsüz komplikasyonlarından biri, bu hastalarda ciddi bir morbidite ile ilişkilendirilen artropatidir. Eklem ilişkili şikayetler ağrı, sertlik veya fonksiyonel kısıtılık gibi, genellikle erken yaşlarda tipik radyolojik anormalliklerle kendisini gösterir. Burada non-travmatik spontan sağ rektus femoris kas rüptürü ve eşlik eden kas içi hematomu olan 24 yaşında akromegalik bir erkek olguyu sunmaktayız.

Anahtar kelimeler: Akromegali, büyüme hormonu, kas rüptürü

\section{Introduction}

Acromegaly is a chronic endocrinopathy characterized by excessive secretion of growth hormone $(\mathrm{GH})$ and consequently increased levels of insulin-like growth factor-1 (IGF-1) (1). The disease usually develops in the second and third decades of life and it is known that females are affected more frequently than males (2). Patients generally present with complaints of fatigue, joint pain, headache and excessive sweating $(3,4)$. However, clinical findings such as somatic disorders, vocal changes and extremity enlargement are considered pathognomonic and support the diagnosis $(5,6)$. Musculoskeletal findings of this syndrome are common and almost all patients develop symptoms or signs of arthropathy. Acromegalic arthropathy occurs in approximately $50 \%$ of the patients, and it is a result of soft tissue and cartilage hypertrophy affecting both the peripheral and axial skeleton due to increased bone turnover associated with excessive GH secretion. In the early stages of the disease, cartilage hypertrophy predominates, and then degenerative changes and osteoarthritic findings occur. Arthropathy can only be reversed when GH and IGF-1 levels return to normal at very early stages of the disease. If the disease is not treated for a long time, osteoarticular sequelae cannot be modified by subsequent acromegaly treatment $(6,7)$. Musculoskeletal findings of acromegaly may be a stimulant for early diagnosis. Thickening of peripheral nerves, such as carpal tunnel or cubital tunnel syndrome, increased disc height and vertebral scalloping (an exaggeration of the normal concavity of the posterior surface of one or more vertebral bodies due to soft-tissue hypertrophy in the spinal canal and increased bone resorption), spondylolisthesis, Baastrup's disease, diffuse idiopathic skeletal hyperostosis, facet hypertrophy and fatty infiltration of the paraspinal muscles are some of the typical musculoskeletal findings of acromegaly $(3,8)$. Due to the insidious course of acromegaly, there are diagnostic delays.

Address for Correspondence/Yazışma Adresi: Nurdan Yılmaz Ass. Prof., Tokat Gaziosmanpaşa University Faculty of Medicine, Department of Physical Medicine and Rehabilitation, Tokat, Turkey

Phone: +90 3562129500 E-mail: nurdanyilmazdr@hotmail.com ORCID ID: orcid.org/0000-0001-5758-6792 Received/Geliş Tarihi: 03.04.2020 Accepted/Kabul Tarihi: 27.07.2020

${ }^{\circ}$ Copyright 2021 by the Turkish Osteoporosis Society / Turkish Journal of Osteoporosis published by Galenos Publishing House. 
The most important therapeutic approach in acromegaly is the early diagnosis at that insidious stage of the disease. In this early stage of the disease, patients refer to many different specialists including musculoskeletal system specialists. The main objective in the treatment of acromegaly is to eliminate morbidity and to make mortality similar to healthy people for the same age group and sex. Therefore, especially musculoskeletal system specialists should recognize the early musculoskeletal manifestations of acromegaly, which is the most common cause of the first referral to health care professionals of acromegalic patients, and direct the suspected patients for endocrinological evaluation. Herein, we present a case of a 24-year-old acromegalic male patient with non-traumatic spontaneous right rectus femoris muscle rupture and accompanying intramuscular hematoma.

\section{Case Report}

A 24-year-old male patient was admitted to our outpatient clinic with pain and swelling on the anterior aspect of his right thigh. The patient's pain was present for less than 24 hours. The patient reported that his pain suddenly began while he was walking downstairs. There was no other history of trauma. On physical examination, knee and hip joint range of motions were complete but painful. There was an increase in stiffness and temperature in the anterior aspect of the right thigh. There was also a $2 \mathrm{~cm}$ diameter increase in the right thigh compared to the left side. The patient's visual analogue scale (VAS) score for his pain was 10 . When the patient's history was questioned, it was learned that he had applied to various clinics with fatigue and joint pain in the last 3 years. Lumbar magnetic resonance imaging (MRI) taken 2 years ago with the complaint of sciatic pain revealed hypertrophy of lumbar facets, increased disc heights of L4-L5 and L5-S1, and left paramedian disc protrusion at L5-S1 level (Figure 1, 2). One year ago, the patient applied to

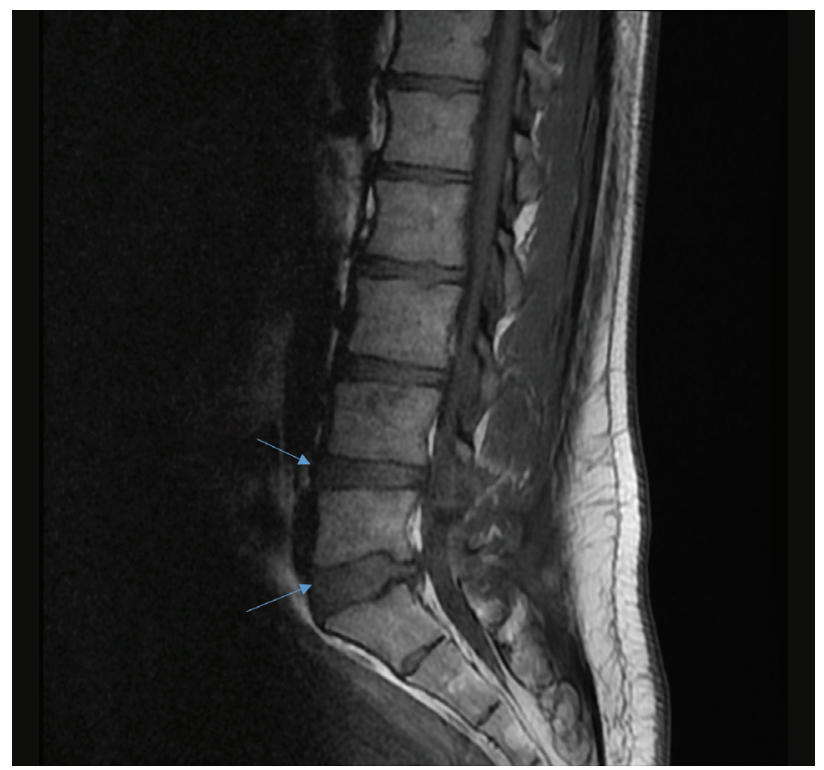

Figure 1. Increased disc heights of L4-L5 and L5-S1 (blue arrows), and left paramedian disc protrusion at L5-S1 level the endocrinology clinic with complaints of fatigue, enlargement in hands and feet, and excessive sweating. In the pituitary MRI, a $19 * 16.9 \mathrm{~mm}$ diameter macroadenoma was detected in the left half of the pituitary gland extending from the central section of the pituitary gland. The patient underwent transsphenoidal pituitary surgery with the diagnosis of acromegaly. The patient was using long-acting somatostatin analogue (lanreotide subcutaneous $60 \mathrm{mg} 1$ *1-per month) and prolactin inhibitor (0.5 mg cabergoline $1 * 1-2$ times per week) post-operatively. There was no pathological finding in the laboratory examinations. The platelet count was 228,000; activated partial thromboplastin time, prothrombin time and international normalized ratio were within normal ranges. Ultrasonographic imaging revealed a $2 \mathrm{~cm}$ transverse hematoma in the widest segment of the right rectus femoris muscle and a partial rupture of the musculotendinous junction at the proximal rectus femoris. In addition to topical and oral nonsteroidal anti-inflammatory treatments, immobilization and cold pack applications ( 3 times per day) were recommended to the patient. On the third day of the treatment, the patient's pain was better and VAS score decreased to 3 from 10.

Our patient was informed about the case presentation, verbal and written informed consents were obtained.

\section{Discussion}

Active acromegaly is associated with severe comorbidity and decreased quality of life (QoL). Joint problems observed in acromegaly are the main cause of the decrease in QoL. Joint complaints appear as the earliest symptom of the disease in a significant proportion of the patients $(9,10)$. The incidence of acromegaly is 2.78 per million-person-years, with little gender predominance (female vs. male, $49.5 \%$ vs. $50.5 \%$, respectively)

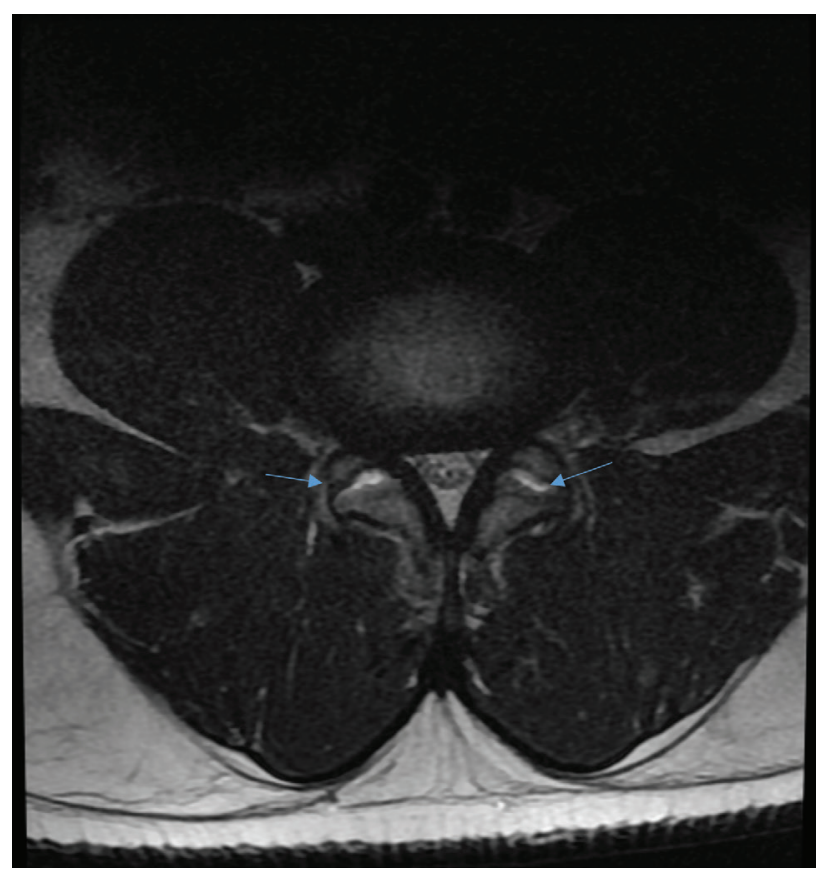

Figure 2. Hypertrophy of lumbar facets (blue arrows) 
(11). The low incidence of the disease may be associated with the diagnostic delay due to the insidious course of the disease (6).

In acromegaly, there is a joint-related comorbidity reaching $77 \%$. Therefore, knowing the typical musculoskeletal findings of acromegaly will provide both early diagnosis and treatment of this rare and insidious disease; as well as early initiation of acromegaly treatment will prevent not only joint-related comorbidity, but also cardiovascular, metabolic, respiratory and psychosocial comorbidities $(8,9)$. Arthropathy in acromegaly has been known since Pierre Marie's classic definition of the disease in 1886 (5). Joint-related complaints such as pain, stiffness or functional limitations are often seen with typical radiological abnormalities at very early ages (12). Both weightbearing and non-weight-bearing joints are affected. Notably, even after long-term remission of acromegaly, the prevalence of clinical and radiographic osteoarthritis is 12 times higher than in the general population (13). There are two basic mechanisms in the pathogenesis of acromegalic arthropathy; the first is endocrine changes, the second is mechanical changes. In the early course of the disease, high levels of $\mathrm{GH}$ and IGF-1 cause hypertrophy of articular cartilage and periarticular ligaments (7). During this period, there is a pseudo expansion in the joint space. In lumbar vertebral imaging, an increase in the intervertebral disc distance and vertebral scalloping can be observed (8). Changing joint structure with recurrent intra-articular trauma and further deterioration of the joint with an exaggerated repair reaction leading to subchondral cysts and osteophyte formations occurs and arthropathy due to biomechanical changes becomes irreversible $(8,13)$. Acromegalic arthropathy includes the lumbar spine and also peripheral joints such as shoulder, knee, wrist, hip and fingers $(8,9,14)$. Considering the age of our patient, the findings in lumbar MRI taken before the acromegaly diagnosis were characteristic changes for acromegaly and could be a stimulant for early diagnosis.

In the literature, there were no reports of spontaneous tendon rupture associated with acromegaly. However, it is known that some endocrinopathies such as diabetes mellitus and hyperparathyroidism, various rheumatic diseases such as lupus or gout, drug using such as quinolone or glucocorticoids, chronic renal failure and renal transplantation can cause spontaneous tendon rupture without significant mechanical bearing (15).

The non-traumatic spontaneous tendon rupture in our patient may be associated with acromegaly-related endocrine disorders and changes in joints, muscles and ligaments (10). In addition, it is known that somatostatin analogs reduce the nociceptive responses by affecting the central and peripheral nervous system (16). This may have weakened the muscle tendon due to chronic uncontrolled loading.

Acromegaly is a rare and insidious disease. However, joint complaints are frequently observed in acromegaly and show some characteristic features. For this reason, the knowledge of the musculoskeletal system findings of acromegaly by radiologists and physiatrists who are especially interested in the musculoskeletal system; will enable early diagnosis and treatment of this insidious disease, in which cardiac, respiratory, metabolic and psychosocial comorbidity is frequently observed.

\section{Ethics}

Informed Consent: Written informed consent was obtained from the patient prior to the drafting of the manuscript.

Peer-review: Externally peer-reviewed.

\section{Authorship Contributions}

Surgical and Medical Practices: N.Y., P.G.O., Concept: N.Y., P.G.O., Design: N.Y., P.G.O., Data Collection or Processing: N.Y., P.G.O., Analysis or Interpretation: N.Y., P.G.O., Literature Search: N.Y., P.G.O., Writing: N.Y., P.G.O.

Conflict of Interest: No conflict of interest was declared by the authors.

Financial Disclosure: The authors declared that this study received no financial support.

\section{References}

1. Katznelson L, Laws ER Jr, Melmed S, Molitch ME, Murad MH, Utz A, et al. Acromegaly: an endocrine society clinical practice guideline. J Clin Endocrinol Metab 2014;99:3933-51.

2. Forgacs SS. Acromegaly: In: Hochberg MC, Silman AJ, Smolen JS, Weinblatt ME, Weisman MH, editors. Rheumatology. 3rd ed. Philadelphia: Mosby; 2003. p. 1967-72.

3. Colao A, Ferone D, Marzullo P, Lombardi G. Systemic complications of acromegaly: epidemiology, pathogenesis, and management. Endocr Rev 2004;25:102-52.

4. Ben-Shlomo A, Melmed S. Acromegaly. Endocrinol Metab Clin North Am 2001;30:565-83.

5. Marie P. Sur deux cas d'acromegalie. Rev Med 1886;6:297-9.

6. Reid TJ, Post KD, Bruce JN, Nabi Kanibir M, Reyes-Vidal CM, Freda PU. Features at diagnosis of 324 patients with acromegaly did not change from 1981 to 2006: acromegaly remains under-recognized and under-diagnosed. Clin Endocrinol (Oxf) 2010;72:203-8.

7. Colao A, Pivonello R, Scarpa R, Vallone G, Ruosi C, Lombardi G. The acromegalic arthropathy. J Endocrinol Invest 2005;28(8 Suppl):24-31

8. Tagliafico A, Resmini E, Ferone D, Martinoli C. Musculoskeletal complications of acromegaly: what radiologists should know about early manifestations. Radiol Med 2011;116:781-92.

9. Biermasz NR, Pereira AM, Smit JW, Romijn JA, Roelfsema F. Morbidity after long-term remission for acromegaly: persisting joint-related complaints cause reduced quality of life. J Clin Endocrinol Metab 2005;90:2731-9.

10. Killinger Z, Payer J, Lazúrová I, Imrich R, Homérová Z, Kužma $M$, et al. Arthropathy in acromegaly. Rheum Dis Clin North Am 2010;36:713-20.

11. Wu JC, Huang WC, Chang HK, Ko CC, Lirng JF, Chen YC. Natural history of acromegaly: incidences, re-operations, cancers, and mortality rates in a national cohort. Neuroendocrinology 2020;110:977-87.

12. Wassenaar MJ, Biermasz NR, Bijsterbosch J, Pereira AM, Meulenbelt I, Smit JW, et al. Arthropathy in long-term cured acromegaly is characterised by osteophytes without joint space narrowing: a comparison with generalised osteoarthritis. Ann Rheum Dis 2011;70:320-5

13. Wassenaar MJ, Biermasz NR, van Duinen N, van der Klaauw AA, Pereira AM, Roelfsema F, et al. High prevalence of arthropathy, according to the definitions of radiological and clinical osteoarthritis, in patients with long-term cure of acromegaly: a case-control study. Eur J Endocrinol 2009;160:357-65. 
14. Colao A, Marzullo P, Vallone G, Marinò V, Annecchino M, Ferone $D$, et al. Reversibility of joint thickening in acromegalic patients: an ultrasonography study. J Clin Endocrinol Metab 1998;83:2121-5.

15. Glick R, Epstein DS, Aponso DT. Spontaneous bilateral quadriceps tendon rupture associated with norfloxacin. Intern Med J 2015;45:1313-5.
16. Carlton SM, Du J, Davidson E, Zhou S, Coggeshall RE. Somatostatin receptors on peripheral primary afferent terminals: inhibition of sensitized nociceptors. Pain 2001;90:233-44. 